AnNa Delekta

Uniwersytet Pedagogiczny, Kraków, Polska

\title{
Integracja systemów rezerwacyjnych w kontekście gospodarki opartej na wiedzy
}

\section{Travel Reservation System Integration in the Context of a Knowledge-based Economy}

\begin{abstract}
Streszczenie: Niniejszy artykuł przybliża pojęcie Globalnego Systemu Dystrybucji (Global Distribution System - GDS) jako systemu zaprojektowanego z myślą o dystrybucji usług lotniczych. Przedstawia obecne rozwiązania integracji usług kolejowych z usługami lotniczymi oraz wskazuje obszary, które będą wyzwaniem dla próbujących dokonać tego typu integracji na większą skalę. $Z$ drugiej strony zaprezentowane jest porównanie usługi podróżnego, który w epoce szybkich i wygodnych kolei staje przed wyborem środka transportu.

Jako przykłady integracji zostają przedstawione ostatnio podpisane umowy partnerskie pomiędzy wybranymi europejskimi przewoźnikami kolejowymi a głównymi Globalnymi Systemami Dystrybucji. Współpraca pozwoli na dystrybucję oferty przewoźników kolejowych poprzez wszystkie kanały przodujących systemów GDS. Dzięki tego typu porozumieniom właściciele kolei wielkich prędkości będą mogli dotrzeć do nowych segmentów rynku, jednocześnie rozszerzając dystrybucję swojej oferty poza tradycyjne kanały i zwiększając swoją obecność na tak strategicznych rynkach jak Europa Środkowa, Ameryka Północna i Azja. To innowacyjne rozwiązanie ma ułatwić i uelastycznić wybór i rezerwację biletów kolejowych przez biura podróży, a w efekcie zapewnić klientom korzystającym z szybkiej kolei wygodną rezerwację i obsługę połączenia, w pełni dostosowaną do ich potrzeb.
\end{abstract}

\begin{abstract}
This article brings up the term of Global Distribution System (GDS) as a system that has been primarily designed and created to distribute airline content. It shows some current integration solutions of rail and airline systems and points out the areas where parties may encounter various challenges trying to build such integration on a larger scale. On the other hand the article presents the comparison of rail and airline offers available to travelers, who, in the era of high speed and super comfortable trains are facing with the choice of means of transport.

As an example of initiatives towards integration, the article discusses some recently signed global distribution agreements between European rail companies and leading representatives of GDS.

This kind of cooperation will allow rail owners to distribute their offer through the existing GDS sales channels. This, in turn, will allow the owners of high speed trains to draw on new market segments whilst expanding distribution beyond its traditional channels, developing its presence in such strategic markets as Central Europe, North America and Asia. This innovative solution will provide travel agencies with greater ease and flexibility when selecting and booking a travel and, as a result, rail customers
\end{abstract}


will be able to enjoy a more convenient booking and railway line operation that will satisfy the needs of modern travellers.

Słowa kluczowe: Globalny System Dystrybucji; integracja systemów; pociągi; szybka kolej

Key words: Global Distribution System; high speed trains, rail; systems integration

\section{WPROWADZENIE}

Zwiększająca się mobilność mieszkańców naszego globu generuje popyt na usługi transportowe. Najdynamiczniej rozwijającą się gałęzią transportu jest współcześnie transport lotniczy. Potwierdzają to badania globalnych prognoz Oxford Economics, raport dla branży turystycznej opublikowany przez firmę Amadeus pod tytułem The Travel Gold Rusch 2020 (www.amadeus.com), a także informacje zamieszczone na stronach Światowej Organizacji Turystyki (www.unwto.com). Ostatnie lata przynoszą jednak coraz więcej wzmianek o intensywnym rozwoju nowego, innowacyjnego środka transportu - zaawansowanej technologicznie kolei wielkich prędkości. Staje się ona w coraz większym stopniu konkurencyjna dla transportu lotniczego (przez rozbudowę sieci połączeń, podnoszenie jakości usług oraz obniżanie ceny za przejazd). Prognozy na najbliższe lata (do roku 2020) podają, że szybka kolej stanie się dominującym środkiem transportu dla wyjazdów w granicach europejskich oraz dla podróży o charakterze służbowym, a liczba jej pasażerów będzie wynosiła 330 milionów (www.amadeus.com).

Kolejnym czynnikiem zwiększającym konkurencyjność połączeń kolejowych jest stworzenie nowych możliwości rozpowszechniania informacji o dostępnych usługach w sieciach komputerowych. W dalszej części artykułu przedstawiono przykłady umów z ostatnich dwóch lat, zawartych pomiędzy właścicielami kolei wielkich prędkości a właścicielami największych globalnych kanałów dystrybucji. Celem jest zintegrowanie lotniczych i kolejowych systemów informatycznych. Integrację systemów rozumiemy tutaj jako ich zespolenie, tak aby mogły one korzystać nawzajem ze swych zasobów.

Integracja systemów i poszukiwanie nowych rozwiązań informatycznych wymagają olbrzymich nakładów zarówno na kapitał intelektualny, jak i na technologię informacyjną, które są rdzeniem gospodarki opartej na wiedzy (Edvinsson, Malone, 2001).

Celem artykułu jest przedstawienie nowatorskich rozwiązań w zakresie współpracy między globalnymi systemami dystrybucji, obsługującymi głównie linie lotnicze, a liniami kolejowymi.

\section{Globalne Systemy Dystrybucji}

Terminem Globalne Systemy Dystrybucji (GDS - Global Distributions System) określa się systemy informacji, komunikowania się, rezerwacji i dystrybucji usług turystycznych. 
Są to komputerowe bazy danych wykorzystywane przez biura podróży do przeglądania i rezerwowania wszystkich rodzajów produktów turystycznych w każdym miejscu na świecie. Pierwotnie zostały utworzone na potrzeby linii lotniczych, ale z czasem objęły swoim zasięgiem cały przemysł turystyczny.

Historia systemów rezerwacji komputerowej rozpoczęła się w Stanach Zjednoczonych już 60 lat temu i jest nierozerwalnie związana z transportem lotniczym. Idea pierwszego systemu GDS narodziła się podczas przypadkowego spotkania dwóch panów Smith w 1953 roku, gdy obaj lecieli liniami American Airlines z Los Angeles do Nowego Jorku. Spotkanie ówczesnego prezesa tejże linii lotniczej (C.R. Smith) i starszego konsultanta ds. sprzedaży w koncernie IBM (R. Blair Smith) zaowocowało pomysłem opracowania systemu przetwarzania danych rezerwacji lotniczych, który umożliwiałby natychmiastowy elektroniczny dostęp do tych danych poprzez sieci telekomunikacyjne. System ten nazwano CRS (Computer Reservation System - Komputerowy System Rezerwacji). Początkowo systemy CRS były dostępne i stosowane wyłącznie przez ich właścicieli, czyli linie lotnicze, służąc do rezerwacji biletów lotniczych. W latach 80 . w obawie przed utratą klientów przez agencje usług, np. touroperatorów, przeprojektowano dotychczasowy Komputerowy System Rezerwacji CRS i zaczęto tworzyć systemy GDS (Delekta, A., Delekta, W., Stecko, J., 2009). Zdaniem D. Buhalisa takie przekształcenie pozwoliło im przeobrazić się w elektroniczne supermarkety turystyczne, oferujące dostęp do całej gamy produktów turystycznych (Buhalis, 2003). Stopniowo rozszerzano geograficzny i operacyjny zasięg działania GDS przez integrację horyzontalną z innymi systemami lotniczymi oraz poprzez integrację pionową, polegającą na włączeniu wielu usług turystycznych (Gaworecki, 2003).

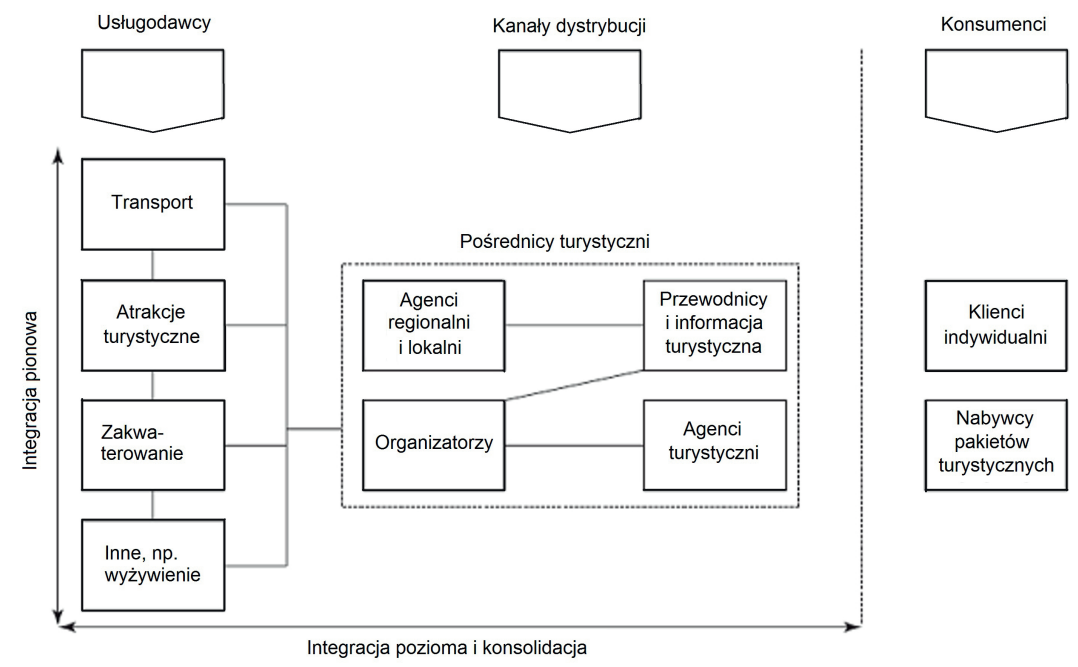

Ryc. 1. Model powiązań na rynku turystycznym

Źródło: Structure, Performance and Competitiveness of European Tourism and its Enterprises. (2003). Luxemburg: Office for Official Publications of the European Communities 7 
Obecnie na światowym rynku turystycznym wyróżnia się 4 największe systemy GDS: Amadeus, Galileo, Worldspan i SABRE oraz 3 właścicieli tych systemów: Amadeus, Travelport, SABRE.

\section{WSPÓŁPRACA GDS Z PRZEWOŹNIKAMI KOLEJOWYMI}

Od pewnego czasu znaleźć można wiele artykułów o próbach integracji systemów GDS z systemami rezerwacyjnymi przewoźników kolejowych. We wrześniu 2010 roku została podpisana umowa pomiędzy firmą Amadeus i Narodowym Towarzystwem Kolei Francuskich SNCF (Société Nationale des Chemins de Fer Français), które rozpoczęły współpracę mającą na celu usprawnienie i ułatwienie dystrybucji oferty SNCF do biur podróży. Jest tam mowa o rozwinięciu dystrybucji oferty SNCF i rozszerzeniu technologii E-ticketing (e-bilet), która miała objąć większość połączeń krajowych we Francji oraz połączeń międzynarodowych. „Przy zakupie e-biletu podróżni otrzymują drogą mailową plik PDF z kodem. Dokument ten należy wydrukować, tak jak w przypadku rezerwacji biletu lotniczego czy samochodu. Takie rozwiązanie przynosi podróżnym korzyści w postaci bezproblemowej odprawy, czy też możliwości zwrotu lub wymiany biletu przez telefon lub stronę internetową" (www.turinfo.pl).

Jednak dopiero w roku 2012 mówi się o intensywnym rozszerzaniu współpracy pomiędzy właścicielami GDS a przewoźnikami kolejowymi, czego potwierdzeniem są informacje o zawartych umowach. Najbardziej aktywnym i najczęściej opisywanym w literaturze przedmiotu integratorem od strony GDS wydaje się firma Amadeus, która, jak deklaruje na swoich stronach, stawia sobie za cel „stworzenie wielokanałowej platformy dystrybucyjnej dla kolei. Kluczem do sukcesu jest dostarczenie dostępu i możliwości powszechnie obecnych w sektorze lotniczym, dlatego międzynarodowa dystrybucja jest dziś tak ważna dla kolei” (www.amadeus.com).

Strony internetowe firmy Amadeus prezentują bardzo bogatą gamę produktów wspierających zarządzanie i dystrybucję ofert przewoźników kolejowych. Pod ogólną nazwą Amadeus Total Rail firma promuje swoje produkty, twierdząc, że „,nadeszła złota era dla pociągów”. Produkty mają wspierać biznes przewoźnika poprzez umożliwienie sprzedaży miejsc w pociągach przez wiele kanałów dystrybucji tymi samymi narzędziami, których agenci biur podróży używają do sprzedaży biletów lotniczych (http://www.amadeus.com/ railwaycompanies/x194035.html).

Tabela 1 przedstawia poszczególne rozwiązania z oferty Amadeus Total Rail.

Jedną z umów podpisanych przez Amadeus w roku 2012 jest umowa z 24 kwietnia z Narodowym Towarzystwem Kolei Francuskich SNCF o umocnienie 16-letniej współpracy. SNCF jako pierwszy klient skorzysta z nowych produktów Amadeus Agent Track oraz Amadeus Web Services Track, umożliwiając agencjom online i offline częściowy dostęp do ich oferty. Dodatkowo Amadeus i SNCF zgadzają się rozszerzyć umowę o rozprowadzanie pełnej oferty do końca 2012 roku (www.amadeusrail.net). 
Tab. 1. Produkty z oferty Amadeus Total Rail

\begin{tabular}{|c|c|}
\hline FlyByRail Track & $\begin{array}{l}\text { Platforma dla agentów biur podróży, umożliwiająca dostęp do dokonywania } \\
\text { rezerwacji i sprzedaży usług kolejowych, lotniczych, usług hotelowych } \\
\text { czy wynajmu samochodów w ujednolicony sposób. W sposób tradycyjny } \\
\text { budowany jest PNR (Passenger Name Record) z wykorzystaniem kodów } \\
\text { IATA. }\end{array}$ \\
\hline Agent Track & $\begin{array}{l}\text { Narzędzie przeznaczone do sprzedaży biletów kolejowych, udostępniane } \\
\text { agentom biur podróży. W ujednolicony sposób pozwala zaprezentować } \\
\text { i porównać oferty różnych przewoźników kolejowych, pozwala } \\
\text { zarezerwować i zapłacić za przejazd. W porównaniu z FlyByRail produkt } \\
\text { jest bardziej interaktywny z systemem przewoźnika, przez co daje agentom } \\
\text { większe możliwości. }\end{array}$ \\
\hline Onboard Track & $\begin{array}{l}\text { Oprogramowanie do wydruku biletów kolejowych już podczas podróży. } \\
\text { Konduktorzy używają podręcznych urządzeń, aby wystawić bilet w czasie } \\
\text { podróży, umożliwiając wcześniejsze sprawdzenie dostępności miejsc } \\
\text { i oferowanych taryf. }\end{array}$ \\
\hline Corporate Track & $\begin{array}{l}\text { System do rezerwacji biletów kolejowych dla korporacji. Umożliwia } \\
\text { pracownikom korporacji dostęp do usług wszystkich zintegrowanych } \\
\text { przewoźników w ujednolicony sposób zgodnie z polityką korporacji. }\end{array}$ \\
\hline Reservation Track & Moduł wspierający obsługę podróżnego na dworcach i w call-centrach. \\
\hline Internet Track & $\begin{array}{l}\text { Zestaw narzędzi do tworzenia własnych portali internetowych do sprzedaży } \\
\text { biletów kolejowych z wykorzystaniem danych udostępnianych przez } \\
\text { zintegrowane systemy Amadeus GDS i systemy przewoźników kolejowych. }\end{array}$ \\
\hline Web Services Track & $\begin{array}{l}\text { Zestaw narzędzi udostępniających dane do tworzenia własnych systemów do } \\
\text { sprzedaży biletów kolejowych. }\end{array}$ \\
\hline Mobile Track & $\begin{array}{l}\text { Kompletny mobilny system do rezerwacji biletów kolejowych, umożliwiający } \\
\text { właścicielom nowych telefonów komórkowych wyszukanie połączenia, } \\
\text { zarezerwowanie biletu. Po opłaceniu takiego biletu w telefonie komórkowym } \\
\text { ukazuje się bilet elektroniczny w formie kodu 2D. }\end{array}$ \\
\hline Kiosk Track & Oprogramowanie do automatów służących do sprzedaży biletów. \\
\hline
\end{tabular}

Źródło: opracowanie własne

Od czerwca 2012 firma Amadeus udostępnia biurom podróży w Polsce europejski produkt kolejowy Deutsche Bahn. Od niedawna przez platformy Amadeus Tour Suite i Amadeus Tour Suite Integrated możliwe jest dokonywanie rezerwacji, a także sprzedaż biletów kolejowych znajdujących się w ofercie niemieckiego operatora, również tych dotychczas niedostępnych w Polsce. Oprócz szerokiej sieci połączeń i taryf, dzięki ofercie Deutsche Bahn klienci mogą kupować bilety innych europejskich przewoźników, w tym polskich. Przez niemieckiego operatora można wystawić bilet na odcinki obsługiwane przez polskich przewoźników (z dogodnymi warunkami rezerwacji i możliwością rezygnacji z biletu) na trasach Poznań-Warszawa i Kraków-Warszawa. Dostępne są również połączenia międzynarodowe do Warszawy, Szczecina, Poznania, Wrocławia i Krakowa. Ceny za przejazd Warszawa-Berlin w opcji „Europa Spezial” zaczynają się od 29 euro (4 razy dziennie), zaś na odcinku Poznań-Berlin - od 19 euro. Z kolei opcja „Euro Night”, czyli wygodne podróżowanie nocą 
po Europie, obejmująca trasę Warszawa-Amsterdam, kosztuje od 29 euro. Dzięki specjalnej promocji na przejazd m.in. pociągiem nocnym City Night Line, bilet na trasie Berlin-Paryż można nabyć w cenie od 39 euro. Z tej bogatej gamy produktów korzystają już biura podróży w Warszawie, Poznaniu, Wrocławiu, Krakowie, Bydgoszczy, Toruniu, Szczecinie, Łodzi i Rzeszowie, które nabyły licencję DB (www.amadeus.com/pl).

Istotnym dokumentem jest umowa podpisana 26 czerwca 2012 roku pomiędzy Amadeus a włoskim przewoźnikiem Trenitalia, wydziałem transportu Italian FS Group. Umowa partnerska ma pozwolić na dystrybucję oferty Trenitalia poprzez wszystkie kanały dystrybucji Amadeus. „Biura podróży na całym świecie zyskają możliwość rezerwowania biletów zarówno na pociągi szybkiej kolei Frecce Alta Velocità (a więc Frecciarossa oraz Frecciargento), jak i pociągi Frecciabianca poprzez istniejące kanały sprzedaży i globalny system dystrybucyjny Amadeus, który obejmuje 91 tysięcy punktów sprzedaży na całym świecie. Pozostałe średnioi długodystansowe trasy Trenitalii także będą dostępne w najbliższym czasie" (www.amadeus.com/pl). Umowa jest szczególnie istotna, ponieważ wspomina o produkcie FlyByRail, dzięki któremu biura podróży uzyskają wystandaryzowany dostęp do usług Trenitalii, przez rozwiązanie służące zarówno do wyszukiwania lotów, jak i podróży koleją. Dzięki temu i biura podróży, i turyści będą mogli znacznie łatwiej i efektywniej porównywać usługi Trenitalii z lotami dostępnymi na tej samej trasie. W ten sposób podróżni zyskają większy wybór i przejrzystość opcji, zaś praca agentów stanie się jednocześnie bardziej efektywna. Dodatkowo agenci będą mieli dostęp do oferty Trenitalii poprzez narzędzie do dokonywania rezerwacji kolejowych - Rail Agent Track, zaprojektowane specjalnie dla usług kolejowych (www.amadeus.com/pl, www.amadeusrail.net).

Należy odnotować również podpisaną przez Amadeus umowę z 30 listopada 2012 z największym szwedzkim przewoźnikiem kolejowym Swedish Rail Operator SJ. Umowa ma na celu rozszerzenie obecnej współpracy na udostępnianie usług przewoźnika kolejowego poprzez dodatkowe kanały dystrybucji, jakie oferuje Amadeus. Mówi się tutaj o nowych produktach Amadeus Agent Track oraz Web Services Track, które powstały jako produkty przeznaczone do usług przewozów kolejowych dla agencji online i offline. Do tej pory SJ używało tylko rozwiązania Amadeus e-Travel Management, które było szeroko wykorzystywane przez korporacje w Skandynawii (http://www.amadeusrail.net/news/swedish-rail-operator-sj-joins-the-amadeus-rail-gds.html).

Z kolei firma Sabre Holdings (wspomniany właściciel GDS) na swoich stronach opisuje 11 różnych produktów i integrację z 37 przewoźnikami kolejowymi. Jako partnerzy wymienieni są: AccesRail (integrator niektórych usług kolejowych Renfe, BritRail, East Japan Rail, SNCB, Thalys, który udostępnia oferty tych przewoźników w standardzie podobnym do standardów obowiązujących linie lotnicze), Amtrak (amerykańskie linie kolejowe - dostęp oparty na starszej technologii MultiAccess), SNCF (Francuskie linie kolejowe - dostęp oparty na starszej technologii MultiAccess), Deutsche Bahn, Swedish Rail, RENFE (odpowiednio przewoźnik niemiecki, szwedzki i hiszpański - dostęp przez dedykowaną stronę internetową) (www.sabretravelnetwork.com).

Na podstawie tego opisu trudno byłoby doszukać się silnego trendu i chęci rozbudowy współpracy oraz rozszerzenia gamy produktów służących do integracji Sabre GDS z przewoźnikami kolejowymi. Zgodnie z umową z lutego 2011 z niemieckim przewoźnikiem 
Deutsche Bahn (http://www.breakingtravelnews.com/news/article/sabre-deutsche-bahn-expand-partnership) Sabre Travel Network oraz Deutsche Bahn, dostawca międzynarodowych usług transportowych i logistycznych, rozszerzają dotychczasową współpracę na pozostałym rynku europejskim i światowym, włączając Włochy, Wielką Brytanię, Brazylię i Tajlandię. Agenci Sabre uzyskują w tych krajach możliwość rezerwowania wszystkich usług Deutsche Bahn, używając produktu Sabre Red Rail - rozwiązania bazującego na przeglądarce internetowej.

Natomiast interesująca z punktu widzenia integracji jest umowa z września 2012 pomiędzy Sabre Travel Network i włoskim przewoźnikiem Trenitalia. Wspomniany produkt to Sabre Rail Connect, a oferta ma obejmować szybkie pociągi Frecciarossa, Frecciargento i Frecciabianca. Podobnie jak w przypadku Amadeusa, firma Sabre stawia sobie za cel ujednolicenie systemu do rezerwacji biletów lotniczych z systemem rezerwacji biletów kolejowych, które mają być dostępne dla agentów na całym świecie. Podany został również kod IATA dla przewoźnika Trenitalia - 7T.

Kolejnym przedstawicielem GDS jest grupa Travelport. Informacje na stronach firmy również nie sugerują mocnej kampanii $\mathrm{w}$ celach rozbudowy i integracji systemu z systemami przewoźników kolejowych. Widnieje tam natomiast tekst wyrażający taką potrzebę: „Dostrzegamy wyższy popyt na przejazdy koleją, zarówno u biznesmenów, jak i turystów z całego świata, co jest okazją, aby zwiększyć zasięg i potencjał przychodów. Rozwiązanie Online Travelport, służące do dystrybucji oferty przewozów pociągami, zapewnia zintegrowany punkt dostępu do sprzedaży usług kolejowych dla biur podróży i firm pośredniczących" (http://www.travelport.com/Solutions/Travel-Suppliers/Rail). Mowa jest więc o dystrybucji bez wzmiankowania żadnych konkretnych narzędzi, które mogłyby temu służyć.

Przykładem rozwiązania przeznaczonego dla linii kolejowej jest zaprezentowany produkt Travelport UK Rail, bazujący na przeglądarce internetowej (https://eportal.travelport. com/pages/RailProducts.aspx).

Jeden ze środków rozprowadzania zintegrowanej oferty linii kolejowych przedstawiony został w artykule prezentującym umowę Travelport z integratorem Rail Europe 4A. Dzięki temu porozumieniu użytkownicy portalu Travelport Leisure będą mieli dostęp do rezerwacji niektórych połączeń w Europie, Stanach Zjednoczonych oraz na Dalekim Wschodzie i w Australii, oferowanych przez linie Eurail, Amtrak, VIA Rail, Korail and Japan Rail, Eurostar (http://www.hoteliermiddleeast.com/11692-travelport-ties-up-with-rail-europe).

Ciekawostką i nowością jest natomiast strategiczna umowa podpisana w lutym 2012 roku przez Travelport z Nuovo Trasporto Viaggiatori (NTV), prywatnym przewoźnikiem włoskim, który wprowadził i uruchomił w kwietniu 2012 szybkie pociągi najnowszej generacji Italo - łączące 9 największych miast we Włoszech. Umowa wspomina, że w pierwszej kolejności będą mogły rezerwować usługi Italo lokalne agencje turystyczne we Włoszech, bezpośrednio z narzędzia Travelport Smartpoint App, co sugeruje, że NTV chce nie tylko konkurować z Trenitalią, lecz również z liniami lotniczymi (http://www.ntvspa.it/en/ntv/pagine/1063/Travelport-brings-high-speed-Italian-rail-to-travel-agents.html, http:/www.travolution.co.uk/articles/2012/02/21/5452).

Analizując przedstawione wyżej rozwiązania współpracy systemów GDS z systemami kolejowymi, można wyodrębnić pewne grupy produktów (tab. 2). 
Tab. 2. Efekty współpracy systemów kolejowych z systemami GDS

\begin{tabular}{|l|l|}
\hline \multicolumn{1}{|c|}{ Rozwiązanie } & \multicolumn{1}{|c|}{ Przykład } \\
\hline $\begin{array}{l}\text { Dedykowane portale internetowe lub podsystemy } \\
\text { umożliwiające sprzedaż biletów jednego } \\
\text { konkretnego przewoźnika }\end{array}$ & $\begin{array}{l}\text { Sabre Red SNCF } \\
\text { Sabre Red Deutsche Bahn } \\
\text { Travelport UK Rail } \\
\text { Amadeus Tour Suite Deutsche Bahn } \\
\text { Sabre Amtrak MultiAccess }\end{array}$ \\
\hline $\begin{array}{l}\text { Systemy agregujące i udostępniające } \\
\text { w ujednolicony sposób usługi różnych } \\
\text { przewoźników kolejowych }\end{array}$ & Amadeus Agent Track \\
\hline $\begin{array}{l}\text { Systemy prezentujące dostępność usług kolejowych } \\
\text { wraz z usługami lotniczymi }\end{array}$ & $\begin{array}{l}\text { Amadeus FlyByRail, } \\
\text { Integracja Sabre + Trenitalia (bez nazwy) } \\
\text { Integracja Travelport + NTV Italo }\end{array}$ \\
\hline $\begin{array}{l}\text { Systemy przewoźników kolejowych dostosowane } \\
\text { do standardów IATA dla przewoźników lotniczych }\end{array}$ & $\begin{array}{l}\text { Eurostar widniejący w systemach GDS pod } \\
\text { kodem IATA 9F. }\end{array}$ \\
\hline $\begin{array}{l}\text { Systemy GDS korzystające z danych pochodzących } \\
\text { od firm trzecich, które są integratorami }\end{array}$ & $\begin{array}{l}\text { Sabre + AccesRail } \\
\text { Travelport + Rail Europe 4A }\end{array}$ \\
\hline
\end{tabular}

Źródło: opracowanie własne

Oprócz tego każdy przewoźnik posiada inne kanały dystrybucji swoich usług, które działają bez udziału systemów GDS. Tabela 3 prezentuje najważniejsze z nich wraz z przykładami.

Tab. 3. Aktualne kanały dystrybucji usług kolejowych (przewozy pasażerskie)

\begin{tabular}{|l|l|}
\hline \multicolumn{1}{|c|}{ Rozwiązanie } & \multicolumn{1}{|c|}{ Przykład } \\
\hline Własne platformy internetowe do & http://www.trenitalia.com \\
sprzedaży biletów & $\begin{array}{l}\text { http://www.italotreno.it } \\
\text { http://www.renfe.es } \\
\text { http://www.eur.com } \\
\text { http://www.tgv-europe.com } \\
\text { https://bilet.intercity.pl }\end{array}$ \\
\hline $\begin{array}{l}\text { Zintegrowane platformy internetowe do } \\
\text { sprzedaży biletów wielu przewoźników }\end{array}$ & $\begin{array}{l}\text { http://www.eurail.com } \\
\text { http://www.raileurope.com } \\
\text { http://www.eurorailways.com }\end{array}$ \\
\hline $\begin{array}{l}\text { Zintegrowane systemy przewoźnika } \\
\text { kolejowego z partnerem lotniczym }\end{array}$ & $\begin{array}{l}\text { Produkt „Rail\&Fly - The train to the plane” } \\
\text { Współpraca Deutsche Bahn z Lufthansą, umożliwiająca } \\
\text { zakup jednego biletu na samolot wraz z dojazdem } \\
\text { pociągiem do lotniska. Widoczne są również } \\
\text { w systemach GDS niektóre połączenia kolejowe } \\
\text { widniejące pod kodem IATA LH. }\end{array}$ \\
\hline $\begin{array}{l}\text { Sprzedaż bezpośrednia na dworcach } \\
\text { do sprzedaży biletów kolejowych } \\
\text { przewoźnika w biurach podróży }\end{array}$ & \\
\hline
\end{tabular}

Źródło: opracowanie własne 
Mimo tak wielu kanałów dystrybucji linie kolejowe wciąż próbują wyszukiwać nowe rozwiązania służące pozyskaniu nowych klientów. Szczególną sytuację można odnotować we Włoszech. Tam wspomniany przewoźnik NTV 28 kwietnia 2012 roku wprowadził kilka szybkich pociągów na kluczowych połączeniach Turyn-Mediolan-Florencja-Rzym-Neapol. Rozpoczęła się era konkurencji w kolejach dużych prędkości. Od tego czasu państwowy przewoźnik Trenitalia z szybkimi pociągami Freciarossa już nie jest monopolistą. Prawdopodobnie właśnie nowe prywatne pociągi, które stworzyli prezes koncernu Ferrari Luca Cordero di Montezemolo oraz Diego Della Valle, właściciel firmy Tod's, produkującej eleganckie buty i galanterię skórzaną, stały się przyczyną poszukiwań nowych rozwiązań informatycznych, tworzenia nowych kanałów dystrybucji usług, czego skutkiem są podpisane umowy w firmach Amadeus i Sabre Holdings. Jak zostało wspomniane, również NTV nie pozostaje w tyle, podpisując podobną umowę z przedstawicielem GDS, firmą Travelport (http://m.newsweek.pl/opinie,pociag-klasy-ferrari,71120,1,1.html).

Nowe umowy pomiędzy przewoźnikami kolejowymi a przedstawicielami GDS przyczyniają się do współzawodnictwa kolei z liniami lotniczymi. Jak opisuje Amadeus na swoich stronach: „W ostatnich latach liczba osób korzystających z szybkiej kolei Trenitalia AV gwałtownie się powiększyła, osiągając poziom 25 milionów w 2011 roku. W całej Europie nastąpił rozwój w zakresie podróżowania koleją, która jest obecnie uznawana za ważną alternatywę dla transportu lotniczego" (www.amadeus.com).

Z drugiej strony dla właścicieli GDS jest to również szansa na rozszerzenie oferty oraz na zwiększenie przychodów, gdyż każda transakcja z wykorzystaniem systemu GDS wiąże się z niewielką opłatą (fee) za transakcję. Wspomniana liczba 25 milionów pasażerów na rok w samych tylko Włoszech przy opłacie 1 euro od biletu daje kwotę, która niewątpliwie przyczyniła się do współpracy na rzecz integracji systemów.

W dalszej części artykułu zwrócono uwagę na obecny stan szybkich kolei europejskich oraz na oferty europejskich przewoźników pod kątem współzawodnictwa z liniami lotniczymi. Tworzenie dodatkowych kanałów dystrybucji usług kolejowych ma sens tylko przy założeniu, że klient rzeczywiście będzie coraz częściej z tych usług korzystał.

\section{PoRÓWNANIE USŁUG KOLEJOWYCH Z LOTNICZYMI}

Jak wiadomo, korzystanie z połączenia lotniczego wiąże się najczęściej w wysokimi cenami (z wykluczeniem promocyjnych rejsów oferowanych przez tanie linie lotnicze) oraz dodatkowym wydłużeniem całkowitego czasu podróży, związanym z dojazdem do lotniska oraz oczekiwaniem na odprawę i na bagaż po dotarciu do celu. Z punktu widzenia wygody pasażera dochodzą również pewne ograniczenia odnośnie wielkości bagażu oraz zakazu przenoszenia w bagażu podręcznym niektórych rzeczy, np. płynów, kosmetyków. Pokonując samolotem przykładową odległość z Mediolanu do Rzymu, lub odwrotnie, podróżny musi przeznaczyć na lot godzinę. Lotniska Malpensa i Da Vinci są oddalone o około 50 kilometrów od centrów obu miast, tak więc przejazd na lotnisko zajmuje około godzinę. Podróżny 
potrzebuje zatem około 3 godzin oraz dodatkowego czasu na odprawę na lotnisku. Widać więc, że czas 2 godziny i 55 minut, przeznaczony na przejazd pociągiem, jest zdecydowanie krótszy niż podróż samolotem.

Rozbudowa infrastruktury kolejowej nadzorowana jest przez Międzynarodowy Związek Kolei UIC (Union Internationale des Chemins de fer). Jest to organizacja zrzeszająca przedsiębiorstwa zajmujące się transportem kolejowym i reprezentująca je na arenie międzynarodowej, utworzona w roku 1922. Jej siedziba mieści się w Paryżu. Organizacja prowadzi działania na dwóch głównych frontach:

- Koordynacja współpracy między przedsiębiorstwami kolejowymi w celu zwiększenia spójności poszczególnych systemów kolejowych w różnych krajach, co powinno przyczynić się do zwiększenia konkurencyjności tego środka transportu. W tym celu UIC publikuje zarządzenia zawierające wytyczne dotyczące technologii, infrastruktury czy eksploatacji, mające charakter nakazów, zaleceń lub informacji.

- Promocja transportu kolejowego w kołach rządowych i międzynarodowych. W tym celu UIC jest upoważniona do reprezentowania w roli konsultanta sektora transportu kolejowego na forum ONZ. Podobną rolę UIC pełni również wobec rządów poszczególnych krajów oraz licznych organizacji międzynarodowych (www.uic.org).

Rycina 2 prezentuje stan infrastruktury w Europie (2011 rok) oraz plany jej rozbudowy.

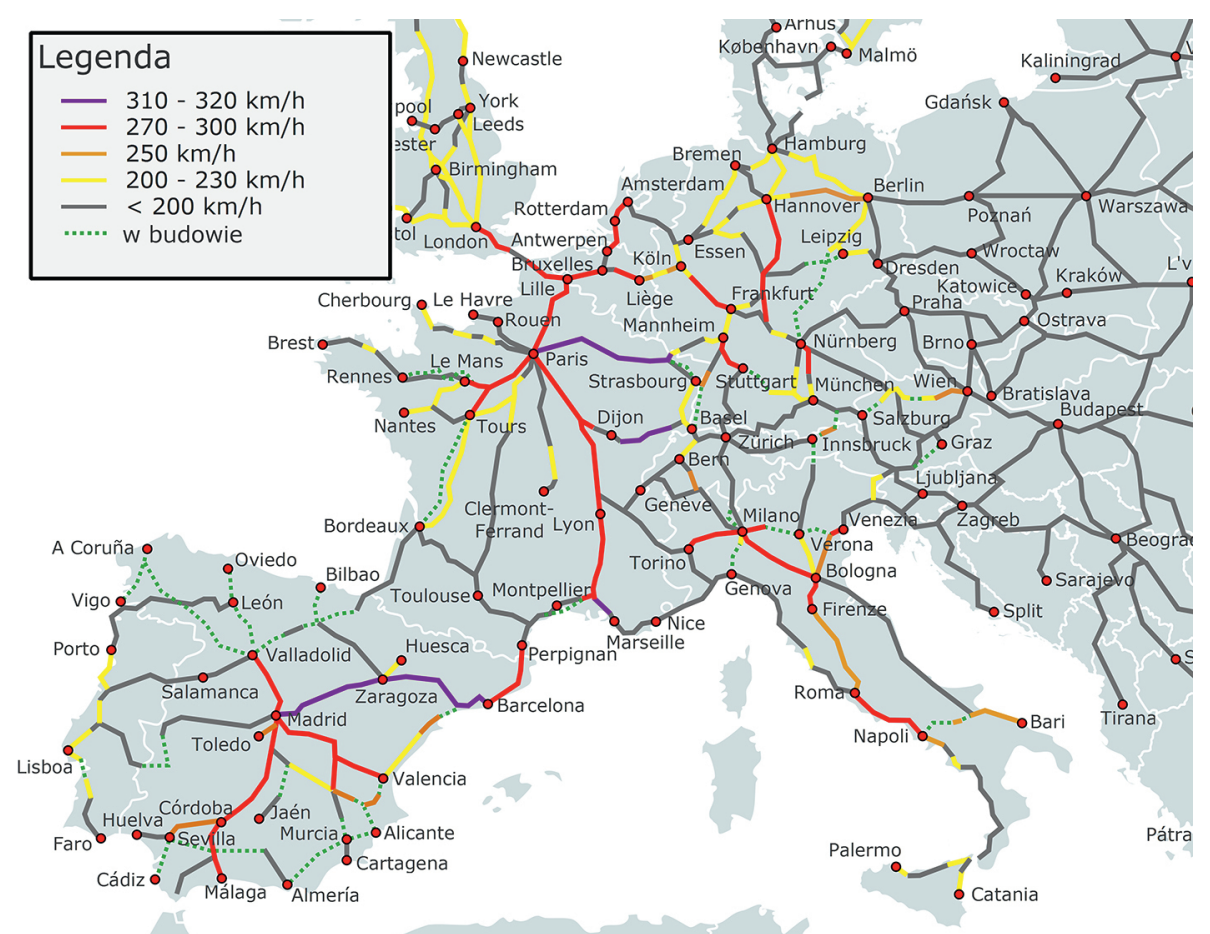

Ryc. 2. Stan infrastruktury kolejowej w Europie w 2011 roku oraz plany jej rozbudowy

Źródło: www.uic.org 
Kraje europejskie najbardziej zaawansowane pod względem infrastruktury wspierającej szybkie pociągi to Francja, Hiszpania, Włochy, Niemcy. W niektórych krajach istnieją ograniczenia prędkości narzucone przez rząd (np. Włochy - $300 \mathrm{~km} / \mathrm{h}$ ). Dane dotyczące funkcjonowania kolei wielkich prędkości we Francji zawiera opracowanie Więckowskiego (Więckowski, 2005), a rozwój szybkich kolei na świecie został szczegółowo przedstawiony w pracy Koziarskiego (Koziarski, 2004).

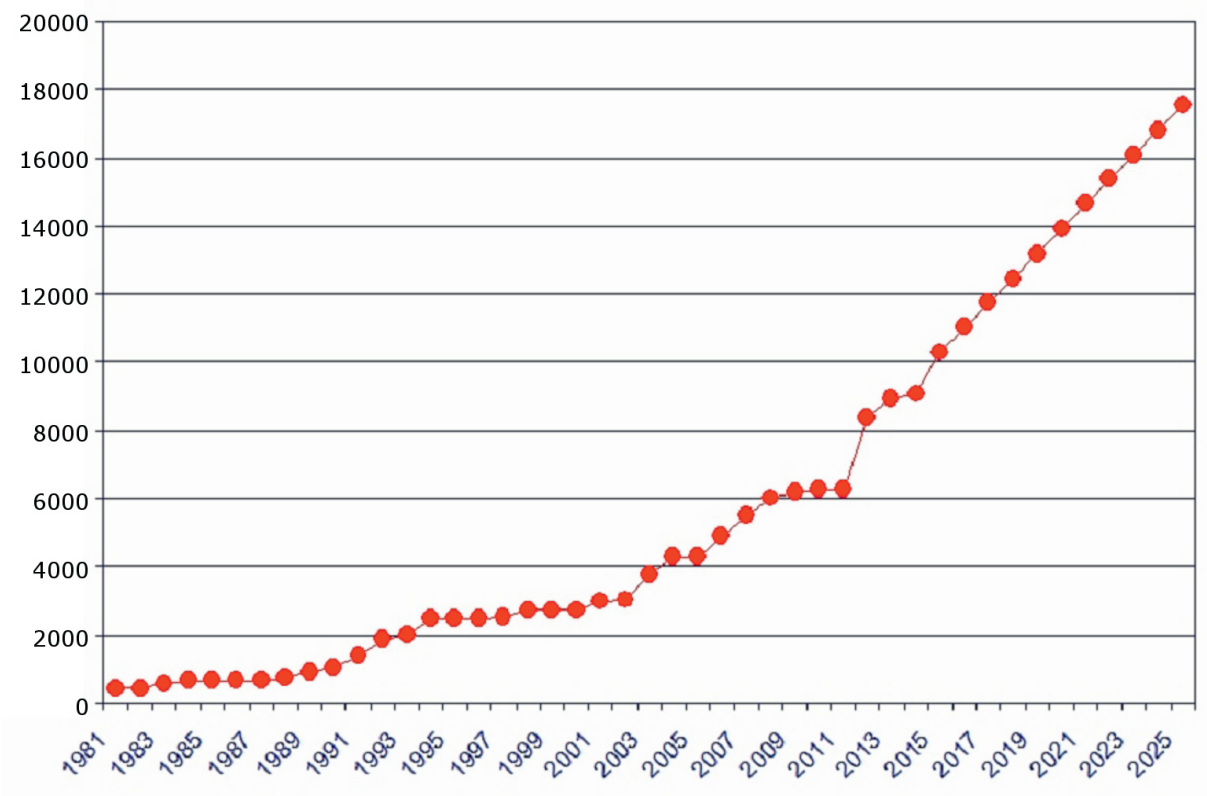

Ryc. 3. Planowany wzrost długości linii kolejowych dużych prędkości w Europie [km]

Źródło: www.uic.org

Tabela 4 przedstawia największych przewoźników kolejowych oferujących przejazdy nowoczesnymi szybkimi pociągami w Europie.

Tab. 4. Zestawienie największych przewoźników kolejowych oferujących transport szybkimi pociągami w Europie

\begin{tabular}{|l|l|}
\hline AVE & $\begin{array}{l}\text { Linie hiszpańskich szybkich pociągów łączą Barcelonę i Madryt, ale również } \\
\text { historyczne miasta andaluzyjskie, takie jak Kordoba czy Sewilla. Przejazd } \\
\text { z Madrytu do Malagi zajmuje tylko 2 godziny } 40 \text { minut. } \\
\text { www.renfe.com }\end{array}$ \\
\hline Eurostar & $\begin{array}{l}\text { Podróż pod kanałem La Manche z centrum Londynu do centrum Paryża lub } \\
\text { Brukseli to tylko 1 godzina 51 minut. } \\
\text { www.eurostar.com }\end{array}$ \\
\hline $\begin{array}{l}\text { Frecciarossa \& } \\
\text { Frecciargento, } \\
\text { Italo }\end{array}$ & $\begin{array}{l}\text { Włoskie szybkie pociągi łączą centra miast, takich jak: Rzym, Florencja, Wenecja, } \\
\text { Mediolan, Bolonia i Neapol, a dodatkowo umożliwiają łatwy dostęp do niektórych } \\
\text { mniejszych miast. Przejazd na trasie Mediolan-Rzym to niecałe 3 godziny. } \\
\text { www.trenitalia.com, www.italotreno.it }\end{array}$ \\
\hline
\end{tabular}




\begin{tabular}{|l|l|}
\hline ICE & $\begin{array}{l}\text { Prowadzi połączenia do głównych niemieckich miast, takich jak: Frankfurt, } \\
\text { Hamburg, Stuttgart, Monachium, Kolonia i Berlin. Pociągi należące do Deutsche } \\
\text { Bahn osiągają prędkość do 300 km/h. Istnieje też możliwość przesiadki na pociągi } \\
\text { do Szwajcarii, Austrii, Belgii, Danii, Francji oraz Holandii. } \\
\text { www.bahn.com }\end{array}$ \\
\hline TGV & $\begin{array}{l}\text { Sieć szybkich pociągów SNCF we Francji łączy ponad } 20 \text { francuskich miast oraz } \\
\text { ma połączenia do sąsiednich państw, np. Belgii, Luksemburga, Szwajcarii, Włoch } \\
\text { i Niemiec. } \\
\text { www.sncf.fr }\end{array}$ \\
\hline Thalys & $\begin{array}{l}\text { Przewoźnik kolejowy oferujący usługi we Francji, Holandii, Belgii oraz } \\
\text { w Niemczech. Podróż z Brukseli do Amsterdamu trwa niecałe 2 godziny. } \\
\text { www.thalys.com }\end{array}$ \\
\hline X2000 & $\begin{array}{l}\text { Sieć szwedzkich kolei, których pociągi jeżdżą z prędkością 200 km/h. Sieć łączy } \\
\text { Sztokholm z innymi miastami południowej Szwecji; ma również połączenia do } \\
\text { sąsiednich państw. } \\
\text { www.sj.se }\end{array}$ \\
\hline
\end{tabular}

Źródło: opracowanie własne na podstawie www.raileurope.com oraz www.eurail.com

Poniżej (tab. 5) zestawiono czasy przejazdu różnymi środkami transportu między przykładowymi miastami.

Tab. 5. Wybrane europejskie połączenia komunikacyjne

a czas przejazdu różnymi środkami transportu w 2012 r.

\begin{tabular}{|l|c|c|c|c|}
\hline \multicolumn{1}{|c|}{ Połączenie } & $\begin{array}{c}\text { Liczba pociągów } \\
\text { na dzień }\end{array}$ & $\begin{array}{c}\text { Czas przejazdu } \\
\text { pociągiem }\end{array}$ & $\begin{array}{c}\text { Czas przelotu } \\
\text { samolotem }\end{array}$ & $\begin{array}{c}\text { Czas przejazdu } \\
\text { samochodem }\end{array}$ \\
\hline Amsterdam-Bruksela & 10 & $1: 54$ & $4: 20$ & $3: 00$ \\
\hline Amsterdam-Frankfurt & 5 & $3: 46$ & $4: 40$ & $4: 50$ \\
\hline Amsterdam-Paryż & 7 & $3: 18$ & $4: 50$ & $5: 30$ \\
\hline Avinion-Nicea & 7 & $2: 50$ & - & $3: 00$ \\
\hline Avinion-Paryż & 16 & $2: 40$ & $4: 40$ & $6: 50$ \\
\hline Barcelona-Madryt & 26 & $2: 40$ & $4: 35$ & $6: 45$ \\
\hline Berlin-Frankfurt & 14 & $4: 07$ & $4: 35$ & $5: 40$ \\
\hline Bruksela-Frankfurt & 3 & $3: 31$ & $4: 35$ & $4: 30$ \\
\hline Bruksela-Londyn & 10 & $1: 51$ & $4: 40$ & $5: 00$ \\
\hline Bruksela-Paryż & 25 & $1: 22$ & $4: 30$ & $3: 30$ \\
\hline Bordeaux-Paryż & 17 & $3: 00$ & $4: 00$ & $7: 00$ \\
\hline Edynburg-Londyn & 15 & $4: 16$ & $5: 00$ & $7: 30$ \\
\hline Florencja-Mediolan & 21 & $1: 45$ & $4: 30$ & $3: 40$ \\
\hline Florencja-Rzym & 40 & $1: 40$ & $4: 25$ & $3: 20$ \\
\hline Frankfurt-Monachium & 21 & $3: 10$ & $4: 40$ & $4: 10$ \\
\hline Frankfurt-Paryż & 5 & $3: 50$ & $4: 50$ & $5: 50$ \\
\hline Genewa-Paryż & 9 & $3: 09$ & $4: 40$ & $5: 30$ \\
\hline Londyn-Paryż & 17 & $2: 15$ & $4: 40$ & $6: 10$ \\
\hline Lyon-Paryż & 22 & $1: 57$ & $4: 40$ & $4: 45$ \\
\hline Madryt-Sewilla & 22 & $2: 20$ & $4: 30$ & $5: 40$ \\
\hline Marsylia-Paryż & 18 & $3: 00$ & $4: 50$ & $7: 30$ \\
\hline
\end{tabular}




\begin{tabular}{|l|r|r|r|l|}
\hline Mediolan-Wenecja & 18 & $2: 23$ & $5: 00$ & $3: 45$ \\
\hline Mediolan-Zurych & 6 & $3: 41$ & $4: 25$ & $4: 00$ \\
\hline Neapol-Rzym & 34 & $1: 10$ & $4: 25$ & $2: 50$ \\
\hline Paryż-Strasburg & 16 & $2: 17$ & $4: 30$ & $5: 00$ \\
\hline Paryż-Zurych & 3 & $4: 32$ & $4: 35$ & $6: 30$ \\
\hline Praga-Wiedeń & 7 & $4: 05$ & $4: 30$ & $5: 00$ \\
\hline Rzym-Wenecja & 26 & $3: 15$ & $4: 35$ & $6: 00$ \\
\hline
\end{tabular}

Źródło: opracowanie własne na podstawie www.raileurope.com

Jak wskazuje tabela 5, czas podróży samolotem jest w przypadku wymienionych połączeń dłuższy od czasu przejazdu pociągiem. Dzieje się tak dlatego, że do czasu samego przelotu doliczono czas potrzebny na dojazd do lotniska, oczekiwanie na odprawę, oczekiwanie na bagaż oraz czas potrzebny na dotarcie do centrum miasta.

Dodatkową ofertą przewoźników kolejowych, której nie znajdziemy w ofercie linii lotniczych, są bilety wieloprzejazdowe InterRail Pass dla mieszkańców Europy lub EuRail Pass dla pozostałych klientów. W zależności od wybranej kategorii biletu - Global Pass, Select Pass, One Country Pass - upoważnia on do przejazdu odpowiednio: wszystkimi pociągami po całej Europie, pociągami po wybranych państwach Europy lub tylko w wybranym kraju.

Przykładowy cennik InterRail Global Pass przedstawia ceny z 2012 roku w zależności od długości ważności biletu. Bilet ważny jest na przejazdy kolejami państwowymi, niektórymi kolejami prywatnymi oraz niektórymi statkami lub promami. Bilet upoważnia również do znacznych zniżek w wybranych muzeach oraz hotelach.

Tab. 6. Cennik biletów InterRail Global Pass w 2012 roku

\begin{tabular}{|l|l|l|}
\hline \multicolumn{1}{|c|}{ Ważność biletu } & Cena dla osoby dorosłej - klasa 2 & Cena dla młodzieży - klasa 2 \\
\hline 5 wybranych dni z $10 \mathrm{dni}$ & 267 EUR & 175 EUR \\
\hline 10 wybranych dni z 22 dni & 381 EUR & 257 EUR \\
\hline 15 następujących po sobie dni & 422 EUR & 298 EUR \\
\hline 22 następujące po sobie dni & 494 EUR & 329 EUR \\
\hline 30 następujących po sobie dni & 638 EUR & 422 EUR \\
\hline
\end{tabular}

Źródło: opracowanie własne na podstawie www.intercity.pl

\section{POTENCJALNE PROBLEMY INTEGRACJI SYSTEMÓW INFORMATYCZNYCH, LOTNICZYCH I KOLEJOWYCH}

Usługi przewoźników kolejowych różnią się od usług oferowanych przez linie lotnicze. Różnice są widoczne nie tylko w sposobie zakupu biletów, liczbie dostępnych taryf i oferowanych na pokładzie usług. Istnieją zauważalne różnice w samym sposobie przewozu pasażera, które mogą mieć wpływ na integrację dwóch różnych systemów i ją komplikować: 
- w odróżnieniu od podróży samolotem, będącej połączeniem punkt-punkt, pociągi zatrzymują się na pośrednich dworcach, na których mogą wysiadać lub dosiadać się nowi pasażerowie;

- pociągi na swojej trasie mogą łączyć się lub dzielić (np. wyjeżdżający z Rzymu szybki pociąg Trenitalia nr 727 rozdziela się w Mesynie. Jedna część składu kontynuuje przejazd do Katanii, a druga część do Palermo);

- podczas przesiadek pasażer we własnym zakresie dba o bagaż w odróżnieniu od połączeń lotniczych, gdzie bagażem zajmuje się obsługa lotniska.

W dzisiejszych systemach GDS wszystkie połączenia określane są za pomocą pary lotnisk (początkowego i docelowego), którym nadawane są kody przez organizację IATA (np. WAW - Lotnisko Chopina w Warszawie, KRK - Kraków Airport). Próba integracji z systemami lotniczymi może oznaczać konieczność przypisania kodu IATA każdemu dworcowi. $Z$ tym natomiast może być problem, ponieważ liczba kombinacji trójliterowych jest mocno ograniczona.

W ten właśnie sposób, z wykorzystaniem kodów IATA, rozprowadza swoją ofertę przewoźnik kolejowy Eurostar (kod IATA 9F), zintegrowany w systemami GDS we wcześniejszych latach (tab. 7).

Tab. 7. Kody IATA przypisane do dworców, na których operuje pociąg Eurostar

XQE EBBSFLEET KENT, UNITED KINGDOM
QDH ASHFORD RAIL STA, UNITED KINGDOM
QQS LONDON ST PANCRAS, UNITED KINGDOM
ZYR BRUSSELS MIDI, BELGIUM
XJY PARIS DE MASSY RR, FRANCE
XPG PARIS GARE D NORD, FRANCE
XFF CALAIS RR STN, FRANCE
XDB LILLE EUROPE, FRANCE
XZI METZ LORRAINE, FRANCE

Źródło: opracowanie własne na podstawie danych z systemu Galileo Desktop

Po sprawdzeniu informacji zapisanych w systemie Sabre okazuje się, że w przypadku włoskich kolei system rozpoznaje obecnie tylko 13 dworców (tab. 8) z około 3400 istniejących we Włoszech oraz 13 z 38, na których zatrzymują się szybkie pociągi grupy Trenitalia czy NTV.

Wymienione dworce mogą jednak tworzyć sporą siatkę połączeń, dla których systemy GDS wyszukujące oferty umożliwią pojawienie się w rezultatach wyszukiwania połączeń kolejowych wraz z połączeniami lotniczymi, dając agentom możliwość wyboru. Dla pozostałych połączeń i dodatkowych usług specyficznych dla kolei agent będzie musiał skorzystać z dedykowanych produktów, takich jak Amadeus Agent Track. 
Tab. 8. Kody IATA przypisane do dworców we Włoszech w systemie Sabre Red

\begin{tabular}{|l|}
\hline XRJ ROME, ITALY \\
ZMS FLORENCE RAILWAY, ITALY \\
FIR FLORENCE FIRENZE, ITALY \\
TPY TORINO PORTA NUOVA RAIL, ITALY \\
XIK MILAN, ITALY \\
BRZ BRESCIA RAILWAY, ITALY \\
XIX VERONA, ITALY \\
BZQ BOLZANO BOZEN, ITALY \\
XVQ VENICE, ITALY \\
QPA PADOVA, ITALY \\
LTZ LAMEZIA RAILWAY, ITALY \\
RCC REGGIO RAILWAY, ITALY \\
BQD BRINDISI RAILWAY, ITALY \\
\hline
\end{tabular}

Źródło: opracowanie własne na podstawie danych z systemu Sabre Red

\section{PoDSUMOWANIE}

Reasumując, należy stwierdzić, że najbliższe lata mogą przynieść istotne zmiany w zakresie jakości podróżowania. Przyszłość podróży kształtowana będzie przez innowacje technologiczne i nowe rozwiązania komunikacyjne. Jednym z takich rozwiązań jest gwałtowny rozwój szybkiej kolei i współpraca jej właścicieli z systemami GDS w celu integracji systemów informatycznych lotniczych i kolejowych. Już teraz obserwuje się renesans podróżowania koleją, a w ciągu trzech najbliższych lat - jak podkreśla Thomas Drexler, szef działu Amadeus Rail - będziemy świadkami transformacji kolei, która staje się coraz popularniejszym środkiem podróży międzynarodowych (www.dziennikturystyczny.pl) i atrakcyjną alternatywą dla transportu lotniczego.

Na koniec należy dodać, że koleje stają się nie tylko konkurencją dla linii lotniczych, ale obserwuje się również dążenie do współpracy między tymi gałęziami transportu. Wyraża się ono w idei transportu intermodalnego, która opiera się na wykorzystaniu w przewozach więcej niż jednej gałęzi transportu. Rozwój systemów łączących transport lotniczy z innymi rodzajami transportu (głównie koleją) jest nie tylko zbieżny z założeniami Europejskiej Strategii Rozwoju Zrównoważonego i polityki transportowej Unii Europejskiej (European Commission 2009), ale staje się też trendem światowym.

\section{Literatura}

Buhalis, D. (2003). eTourism: Information Technology for Strategic Tourism Management. Harlow: Prentice Hall.

Delekta, A., Delekta, W., Stecko, J. (2009). Globalny System Dystrybucji jako element rozwoju sektora usług turystycznych. Problemy Współczesnego Zarządzania, 3, 63-74.

Edvinsson, L., Malone, M. (2001). Kapitat intelektualny. Warszawa: Wydawnictwo Naukowe PWN. 
Gaworecki, W. (2003). Turystyka. Warszawa: Polskie Wydawnictwo Ekonomiczne.

Koziarski, S. (2004). Szybkie koleje na świecie. Prace Komisji Geografii Komunikacji Polskiego Towarzystwa Geograficznego, 10, 33-106.

Structure, Performance and Competitiveness of European Tourism and its Enterprises. (2003). Luxemburg: Office for Official Publications of the European Communities.

Więckowski, M. (2005). Wybrane aspekty funkcjonowania szybkich kolei we współczesnej Europie, na przykładzie francuskiego TGV. Prace Komisji Geografii Komunikacji Polskiego Towarzystwa Geograficznego, 11, 41-54.

\section{Źródla internetowe}

http://www.amadeus.com/pl/documents/corporate/Travel-Gold-Rush-2020-EN.pdf (dostęp 2.12.2012) http://www.amadeus.com/railwaycompanies/x194035.html (dostęp 15.11.2012)

http://www.amadeusrail.net (dostęp 15.11.2012)

http://www.amadeusrail.net/news/press-release-amadeus-and-sncf-strengthen-partnership.html

(dostęp 2.12.2012)

http://www.bahn.com

https://bilet.intercity.pl (dostęp 5.11.2012)

http://www.breakingtravelnews.com/news/article/sabre-deutsche-bahn-expand-partnership/ (dostęp 10. 11.2012)

http://www.dziennikturystyczny.pl

https://eportal.travelport.com/pages/RailProducts.aspx (dostęp 2.11.2012)

http://www.eurail.com

http://www.eurorailways.com

www.eurostar.com

http://www.hoteliermiddleeast.com/11692-travelport-ties-up-with-rail-europe/ (dostęp 22.11.2012)

http://intercity.pl/pl/dokumenty/Przepisy\%20i\%20taryfy/Mi\%C4\%99dzynarodowe/ Ceny\%20

InterRail\%202012.pdf (dostęp 5.11.2012)

http://www.italotreno.it

http://m.newsweek.pl/opinie,pociag-klasy-ferrari,71120,1,1.html (dostęp 29.01.2011)

http://www.ntvspa.it/en/ntv/pagine/1063/Travelport-brings-high-speed-Italian-rail-to-travel-agents.

html (dostęp 2.12.2012)

http://www.raileurope.com

http://www.renfe.com

http://www.sabretravelnetwork.com

http://www.sj.se

http://www.sncf.fr

http://www.tgv-europe.com/

http://www.thalys.com

http://www.travelport.com/Solutions/Travel-Suppliers/Rail (dostęp 5.11.2012)

http://www.travolution.co.uk/articles/2012/02/21/5452/ (dostęp 21.02.2013)

http://www.trenitalia.com

http://www.turinfo.pl/p/ak_id,10191,,sncf,amadeus,wspolpraca,rezerwacje_kolejowe,dla_europejskich_biur_podrozy,biura.html (dostęp 3.03.2011)

http://www.uic.org

http://www.unwto.com 
Anna Delekta, dr, Uniwersytet Pedagogiczny w Krakowie, Instytut Geografii.

Urodzona w 1978 roku w Przeworsku. Tytuł doktora nauk o Ziemi w zakresie geografii uzyskała na Uniwersytecie Pedagogicznym w Krakowie w 2012 roku. Obecnie zatrudniona w Zakładzie Turystyki i Badań Regionalnych Instytutu Geografii Uniwersytetu Pedagogicznego w Krakowie. Zainteresowania badawcze koncentrują się na problemach turystyki. W szczególności jest to problematyka aktywności turystycznej i destynacji turystycznych różnych grup społeczno-ekonomicznych, problematyka wpływu turystyki na rozwój regionów, miast i obszarów wiejskich oraz zagadnienia wykorzystania technologii informatycznych w gospodarce turystycznej.

Anna Delekta, born in 1978 in Przeworsk. Doctorate Degree in Natural Sciences in the field of Geography gained in 2012 at Pedagogical University of Cracov. Currently employed in Department of Tourism and Regional Research in Institute of Geography at Pedagogical University of Cracov. Research interests focus on the matter of tourism, in particular, on the issues of tourist activity and tourism destination of various socio-economic groups, on the issues of impact of tourism on the development of regions, cities and rural areas as well as the use of information technology in tourism industry.

adres/address: Uniwersytet Pedagogiczny w Krakowie

Instytut Geografii

ul. Podchorążych 2, 30-084 Kraków, Polska

e-mail: adelekta@up.krakow.pl 